\title{
Evaporative performance of single tube and multi tube falling film evaporator prototypes for molten butter: An experimental study
}

\author{
Gaurav S Wale, Pradyuman Barnwal, Ankit Deep and Rahul S Barge
}

Received: 29 June 2018 / Accepted: 25 November 2018 / Published online: 21 February 2019

(c) Indian Dairy Association (India) 2019

\begin{abstract}
This paper presents experimental evaluation of evaporative performance of single tube and multi-tube falling film evaporator prototypes for moisture evaporation from molten butter. For single tube falling film evaporator, steam pressures $\left(1.9 \mathrm{kgf} / \mathrm{cm}^{2}, 2.3 \mathrm{kgf} / \mathrm{cm}^{2}\right.$, and $\left.2.8 \mathrm{kgf} / \mathrm{cm}^{2}\right)$ and film thicknesses $(2$ $\mathrm{mm}, 3 \mathrm{~mm}$ and $4 \mathrm{~mm}$ ) were varied for evaporative performance i.e. steam economy, specific steam consumption, evaporation rate and evaporation ratio. The performance parameters were found statistically significant $(\mathrm{p} \leq 0.05)$ for film thickness and steam pressure and their interactions. The average steam economy $(1.75$ to 1.80$)$ and evaporation rate ( 0.18 to $0.21 \mathrm{~kg} / \mathrm{min})$ was highest whereas average evaporation ratio ( 0.83 to 0.86$)$ was lowest for 2 $\mathrm{mm}$ film thickness for the studied steam pressures. For multitube falling film evaporator, having five tubes in one shell, steam pressure and pump speed were varied for evaporative performance on molten butter. For studied steam pressures, evaporative performance parameters were statistically significant $(\mathrm{p} \leq 0.05)$. For pump speed, evaporation rate and evaporation ratio were statistically significant whereas steam economy and specific steam consumption were statistically non-significant $(p \leq 0.05)$.
\end{abstract}

Gaurav S Wale

ICAR-National Dairy Research Institute (Deemed University), Karnal Karnal-132 001, Haryana, India

Pradyuman Barnwal $(\square)$

ICAR-National Dairy Research Institute (Deemed University), Karnal Karnal-132 001, Haryana, India

E-Mail: pbarnwal@rediffmail.com

Ankit Deep, Rahul S Barge

ICAR-National Dairy Research Institute (Deemed University), Karnal Karnal-132 001, Haryana, India
At $2.8 \mathrm{kgf} / \mathrm{cm}^{2}$ steam pressure and $320 \mathrm{rpm}$ pump speed, highest steam economy and evaporation rate whereas lowest specific steam consumption and evaporation ratio were obtained. It was observed that falling film phenomena may be used for butter oil making with some improvements.

Keywords: Evaporator, Evaporation rate, Falling film, Molten butter, Steam economy

\section{Introduction}

Evaporation is one of the unit operations employed for removal of water (moisture) and subsequently lowering of water activity. It is an important process in the food industry because of its substantial thermal energy requirement. It is used for concentration of products such as milk, skim-milk and whey by the dairy industry (Kessler, 1981; Písecký, 1997). The purpose of evaporation is to remove the solvent (usually water) from a solution so that solute concentration increased with minimum total cost. Generally, the liquid being concentrated flows through a tube whereas heat is applied to the outside of the tube. In this way, solvent boils, vaporises and finally removed from the concentrated liquid (Ahmed, 2003).

Generally, an evaporator is made up of more than one vessel containing tubes. Each vessel is sometimes known as a body or a calandria, whereas some researchers use the term calandria for the bundle of tubes welded between two tube sheets inside a steam chest. The tubes are welded to a tube sheet which is fixed into the vessel. The space created on the outside of the tubes is known as the steam chest. Different types of evaporators are used for evaporation of foods. The selection of evaporator for a particular process depends on the product, economics, and historical preferences of that particular product industry. In published literature, detailed descriptions of various aspects and types of evaporators have been reported e.g. for general information (Minton, 1986; Perry and Green, 1997; Billet, 1989), for citrus juice evaporation (Chen and Hernandez, 1997) and about evaporators in the dairy industry (Bouman et al., 1988).

Butter is a fat rich dairy product, a water-in-oil type emulsion, derived exclusively from milk and / or milk products (Warrier et 
al., 2018; Lee et. al., 2018). It is one of the most popular dairy products in the world having annual production about 10 million metric tons (Warrier et al., 2018; FAO, 2017). Un-ripened butter without the addition of any preservative such as common salt, any added colouring matter or any added flavouring agent is referred as white butter (Warrier et al., 2018; CBSE, 2013). Milk fat or butter fat is the second largest component of milk, having major commercial value. The term milk fat, anhydrous milk fat, dry butter fat, and dehydrated butter fat are used synonymously with butter oil, but the raw material for their preparation is usually cream (De, 1980). It serves nutritionally, an energy source, and supplies essential fatty acids. According to the norms of FAO / WHO, anhydrous milk fat should have fat content of at least 99.8 $\%$ and moisture content of should not be more than $0.1 \%$ (Garg, 2002). As per world dairy situation (World: dairy product output, growth 2005/15), the butter and butter oil production shows 39 $\%$ growth worldwide (Anon 2019).

A falling film evaporator is the most commonly used evaporator type in the dairy industry for the concentration of products such as milk, skim-milk and whey (Cunningham et al. 2006).It is used extensively in the food industry for their ability to process heat sensitive products / materials (Tanguy et al., 2015) such as milk before spray drying and fruit and vegetable juices (Morison et al., 2006). The maximum concentration of any product achievable in a falling-film evaporator is determined mainly by the viscosity of the concentrate (Tanguy et al., 2015, Snoeren et al., 1982). In a falling-film evaporator, liquid enters at the top and flows down in tubes as a film. The vapour and the concentrate leave the bottom (Tanguy et al., 2015, Morison et al., 2006). The minimal fluid residence times and high transfer rates, with relatively low temperature differences are the advantages of such evaporators (Salvagnini and Taqueda, 2004). Actual evaporator performance data for molten mutter are relatively scarce. In present study, single tube and multi tube falling film evaporator (STFFE) prototypes were developed and experimentally evaluated on molten butter for evaporative performance e.g. steam economy, specific steam consumption, evaporation rate and evaporation ratio.

\section{Materials and methods}

\section{Raw material}

Fresh white butter (unsalted sweet cream butter) was procured from Experimental Dairy, ICAR-NDRI Karnal. The moisture content of butter was determined using hot air oven method (FSSAI, 2015).

Moisture, \% (w.b.) by mass $=\frac{M_{1}-M_{2}}{M_{1}-M} \times 100$
Where, $M_{1}=$ mass of the dish with sample before heating to constant weight; $\mathrm{M}_{2}=$ mass of the dish with sample after heating to constant weight; and $\mathrm{M}=$ mass of the empty dry dish.

Total solids content employing the standard gravimetric method for sweetened condensed milk (FSSAI, 2012) may be expressed as:

Total Solids $(\%)=\frac{M_{2}-M}{M_{1}-M} \times 100$

Then using Eqs (1a and 1b),

Total solids content $(\%)=100-$ moisture content $(\%$ wet basis $)$ ...(1c)

\section{Falling film evaporator prototypes}

Single tube falling film evaporator (STFFE) prototype and multitube falling film evaporator (MTFFE) prototypes have been developed at Dairy Engineering Division, ICAR-National Dairy Research Institute, Karnal, Haryana, India for moisture evaporation from molten butter. All direct contact parts were made of stainless steel (SS 304). The STFFE (schematic diagram and fabricated prototype) is shown in Fig. 1. It consists of a balance tank, single evaporating tube, distributor plate and its assembly, steam control valve, steam trap, pressure gauge and support system etc. The technical detail of STFFE is presented in Table 1. Provisions were made to vary the film thickness as $2 \mathrm{~mm}, 3 \mathrm{~mm}$ and $4 \mathrm{~mm}$. The film thicknesses were formed using removable distribution system along with distribution ring. The length of evaporating section was $200 \mathrm{~cm}$. The evaporating portion contains two vertical concentric tubes (evaporating and steam tubes). The balance tank (stainless steel) was used to feed the molten butter through a two-way valve to the evaporating tube. Different distribution plates (12, 14 and $16 \mathrm{~mm}$ diameter) were used for $4 \mathrm{~mm}, 3 \mathrm{~mm}$ and $2 \mathrm{~mm}$ film thicknesses. Fig. 2 represents the MTFFE (schematic diagram and fabricated prototype). It consists of a feed tank (molten butter tank), vapour separator, evaporating tubes (5 numbers in triangular pitch pattern), distributor plate and its assembly, lobe type pump (feed pump or molten butter pump), steam control valve, sight glass, steam trap, pressure gauge, vapour blower (induced draft fan) and support system etc. Table 2 shows the technical details of MTFFE. The vapour separator and vapour blower (induced draft fan) were connected through flexible PTFE (hard type) pipe of $10 \mathrm{~cm}$ diameter. The evaporating portion consists of one vertical shell (for steam) and five vertical tubes (for evaporating liquid). The feed pump was connected through variable frequency drive (VFD) to control or vary the speed of pump.

\section{Instrumentation and experimentation}


MEXTECH Multi-thermometer (range:- $50^{\circ} \mathrm{C}$ to $+300^{\circ} \mathrm{C}$; least count: $0.1{ }^{\circ} \mathrm{C}$ ) was used to measure the temperature of molten butter during product preparation and sample preparation. A portable digital weighing balance (capacity: up to $100 \mathrm{~kg}$; least count: $40 \mathrm{~g}$ ) was used to weigh butter, water and caustic solution etc. Precision electronic balance (Model: KERRO BL3003; least count: $1 \mathrm{mg}$, capacity: $300 \mathrm{~g}$ ) was used for weighing in total solids estimation. A steam jacketed kettle, made of stainless steel (SS), was used for the preparation of molten butter. Steam pressure gauge, pressure release valve, safety valve and steam trap was used for proper control of heating in the kettle. In this kettle, the butter was melted and heated to desired temperature $\left(95\right.$ to $\left.100^{\circ} \mathrm{C}\right)$. Molten butter was accumulated in insulated stainless steel (SS 304) vessel which was covered with lid. Molten butter samples were taken after preparation from this vessel. The vessels were also used for pouring (input) of molten butter in balance tank of evaporator prototypes.

For STFFE prototype, the experiments were conducted using full factorial design for variable parameters such as film thickness (2, $3,4 \mathrm{~mm})$ and operating steam pressure $\left(1.9,2.3,2.8 \mathrm{kgf} / \mathrm{cm}^{2}\right)$ in triplicates. The molten butter $\left(7 \mathrm{~kg}, 95^{\circ} \mathrm{C}\right.$ temperature $)$ was poured into the balance tank using the insulated vessel. Before pouring of the molten butter, sample was taken for initial moisture / total solids etc. of butter. The outlet valve of balance tank was ensured for closed position. Steam supply was obtained by regulating valves and then waited to attain the desired steam pressure. The discharge valve was opened just after collecting vessel was placed at the bottom end of STFFE prototype. The various data e.g. time taken by feed to come down, flow rate, product and condensate temperature, quantity of steam used (from steam condensate) etc. were recorded. The distributor plate was changed for trials to be conducted on other film thicknesses too. The outlet temperature of product ranged from 109.5 to $115^{\circ} \mathrm{C}$. The steam opening valve was closed at end of every single operation. Rinsing was carried out through STFFE prototype with help of $90^{\circ} \mathrm{C}$ hot water for 15 minutes. Two per cent solution of caustic soda was formed in hot water. The steam supply and feed opening valve were opened. The caustic solution was collected in collecting vessels and re-circulated it for 20-25 minutes. Then, rinsing was done with hot water for 15-20 minutes. Above procedure was repeated for all film thicknesses.

For MTFFE prototype, experimental trials were conducted on water as well as molten butter using full factorial design in duplicates. For water, variables were initial temperature of water (40 and $95{ }^{\circ} \mathrm{C}$ ), steam pressure $\left(1.5\right.$ and $\left.2 \mathrm{kgf} / \mathrm{cm}^{2}\right)$ and pump speed $(275,285$ and $320 \mathrm{rpm})$. The pump speeds were adjusted by varying the VFD frequencies and using V-belt pulley to prime mover (motor). For molten butter, the variables were steam pressure $\left(1.9,2.3,2.8 \mathrm{kgf} / \mathrm{cm}^{2}\right)$ and pump speed (285 and 320 $\mathrm{rpm})$. Molten butter $(35 \mathrm{~kg})$ at desired temperature $\left(95^{\circ} \mathrm{C}\right)$ was poured into the feed tank from the insulated vessel. Before pouring of the molten butter to feed tank, sample was taken as initial sample of butter. Care was taken for opening of feed valve before pouring so that priming of the feed pump occurs naturally. After pouring the molten butter to feed tank, feed pump (a lobe type pump) was started. The system undergoes the steaming treatment by opening the steam valve. When steam trap showed its stability with pressure, the experimental trials were started. Then, the molten butter was circulated to evaporator system. After starting the feed pump, molten butter started collecting in a vapour separator where the vapours (moisture) were extracted by the induced draft fan. In vapour separator, a 10 micron SS mesh was fitted to prevent solid losses from the separator. Vapour flow and liquid flow channels were observed through the sight glass provided to the top cover of vapour separator. Evaporated intermediate product was manually put to feed bowl of ghee clarifier with the help of insulated vessels. In this process, sample was taken at three stages e.g. before pouring of the molten butter to feed tank, after moisture evaporation and after the clarification. The temperature readings were recorded e.g. feed temperature, steam inlet and condensate outlet temperatures and reduced moisture butter temperature etc. After evaporation, cleaning-inplace (CIP) was done by circulating hot water $\left(\right.$ at $\left.85-90^{\circ} \mathrm{C}\right)$ for 10 15 minutes. After this, Two per cent solution of caustic soda was formed in hot water at a temperature of $65-70^{\circ} \mathrm{C}$ and circulated for 15-20 minutes through the feed tank, feed pump, calandria and vapour separator etc. The hot water was again circulated for 5-10 minutes. Finally the soft water at room temperature was circulated for 10-15 minutes. Prior to every trial, the hot water was circulated to reduce any microbial-growth which may occur on inner wall of the equipment.

\section{Evaporative performance parameters}

The evaporative performance of STFFE and MTFFE prototypes were determined by using following performance parameters for molten butter:

Steam Economy: It is defined as ratio of mass of the water evaporated in the evaporator to the mass of steam consumed (Minton, 1986). It gives the prediction of mass of steam needed for the amount of water evaporated.

$$
\text { Steam economy }=\left[\frac{\text { Mass of } \text { water evaporated }}{\text { Mass of steam consumed }}\right]
$$

It is expressed as $\mathrm{kg}$ water evaporated $/ \mathrm{kg}$ steam. Mass of steam consumed was equivalent to mass of condensate.

Specific steam Consumption: It is defined as reciprocal of steam economy i.e. amount of steam consumed to evaporate the unit amount of water. 
Specificsteamconsumption $=\left[\frac{1}{\text { Steameconomy }}\right]$

(3)

Evaporation rate: It is defined as amount of water evaporated per unit time of operation $(\mathrm{kg} / \mathrm{min}$.).

Evaporation rate $=\left[\frac{\text { Mass of water evaporated }}{\text { Time of operation }}\right]=\left[\frac{\text { Mass of water evaporated }}{\text { Evaporation time }}\right]$

The amount or mass of water evaporated per hour is referred as capacity (Minton, 1986).

Evaporation Ratio: The evaporation ratio, also referred as concentration ratio, is defined as the ratio of feed concentration to the product concentration.

$$
\text { Evaporatioratio }=\left[\frac{\text { Concentraionof butterat inlet }}{\text { Concentraionof butterat outlet }}\right]
$$

\section{Statastical analysis}

The experimental data were subjected to statastical analysis by using two way ANOVA, PROC ANOVA (SAS sotware, version 9.3). To test the significance difference between the experimental and perdicted values at oprtimum parameters, Tukeys test module $(p \leq 0.05)$ was used. The graphical represention and mathematical calculations were carried out in a MS-EXCEL 2010 software.

\section{Results and discussion}

\section{Steam economy}

For STFFE, the steam economy was statistically highly significant (Table 3). Steam economy showed variation with film thicknesses and steam pressure (Fig.3a). For higher film thickness, lower steam economy was observed. This may be due to the higher heat transfer and evaporation rate because of the less film thickness. The average steam economy ranged from 1.75 to $1.80,0.97$ to 1.17 and 0.68 to 0.85 , for $2 \mathrm{~mm}, 3 \mathrm{~mm}$ and $4 \mathrm{~mm}$ film thicknesses, respectively for the studied steam pressures. For MTFFE on water, the statistical analysis shows that steam economy was significant with steam pressure whereas non-significant with pump speed and initial temperature $(\mathrm{p} \leq 0.05)$. The interaction of all these factors, were found significant (Table 4 ). The average steam economy for $40^{\circ} \mathrm{C}$ initial temperature of water, ranged from 0.63 to 0.95 and 0.92 to 1.01 at $1.5 \mathrm{kgf} / \mathrm{cm}^{2}$ and $2 \mathrm{kgf} / \mathrm{cm}^{2}$ steam pressures, respectively (Fig. 4a). The average steam economy at $1.5 \mathrm{kgf} / \mathrm{cm}^{2}$ and $2 \mathrm{kgf} / \mathrm{cm}^{2}$ steam pressures for $95^{\circ} \mathrm{C}$ initial temperature of water, ranged from 0.83 to 0.91 and 0.91 to 0.96 , respectively. This may occurs due to the initial temperature variation. However, it shows an indication about the maximum amount of steam economy which may be obtained. This also indicates the maximum concentration of any feed product that may be obtained in MTFFE. For molten butter on MTFFE, steam economy is highly non-significant with steam pressure whereas it is significant with pump speed and their interaction (Table 5). From Fig, 5a, it is clear that steam economy increases with steam pressure but not with pump speed. It means that steam pressure may give significant result but not with pump speed. It's average value ranged from the 0.63 to $0.67,0.90$ to 0.92 and 1.03 to 1.06 at

Table 1 Technical specification of single tube falling film evaporator (STFFE) prototype

\begin{tabular}{lc}
\hline Technical details & Value \\
\hline Diameter and thickness (evaporating tube) & $2 \mathrm{~cm} \mathrm{and} 2 \mathrm{~mm}$ \\
Diameter and thickness (outer heating tube) & $4 \mathrm{~cm}$ and $4 \mathrm{~mm}$ \\
Height of heating / evaporating portion & $200 \mathrm{~cm}$ \\
Diameter of stainless steel distributor plate & $12 \mathrm{~mm}, 14 \mathrm{~mm}$ and $16 \mathrm{~mm}$ \\
Distributor plate assembly & Teflon made (support rod SS made) \\
Distributor plate height & $6 \mathrm{~mm}$ \\
Depth (plate assembly) below the inlet & $2 \mathrm{~cm}$ \\
Diameter of support system of distributor plate & $3.8 \mathrm{~cm}$ \\
Total height of support system of distributor plate & $10 \mathrm{~cm}$ \\
Height of distributor plate below the inlet pipe of feed & $2 \mathrm{~cm}$ \\
Height of distributor plate assembly (SS made) & $6 \mathrm{~mm}$ \\
Depth (plate assembly) below the inlet & $2 \mathrm{~cm}$ \\
Total height of support system prototype & $40 \mathrm{~cm}$ \\
Diameter of support system of prototype & $30 \mathrm{~cm}$ \\
Film thickness & $2 \mathrm{~mm}, 3 \mathrm{~mm}, 4 \mathrm{~mm}$ \\
Total length of prototype & $220 \mathrm{~cm}$ \\
Diameter and height of balance tank & $24 \mathrm{~cm} \mathrm{and} 26 \mathrm{~cm}$ \\
\hline
\end{tabular}


Figure 1 Single Tube Falling Film Evaporator (STFFE) prototype (a) Schematic Diagram and

(b) Fabricated STFFE

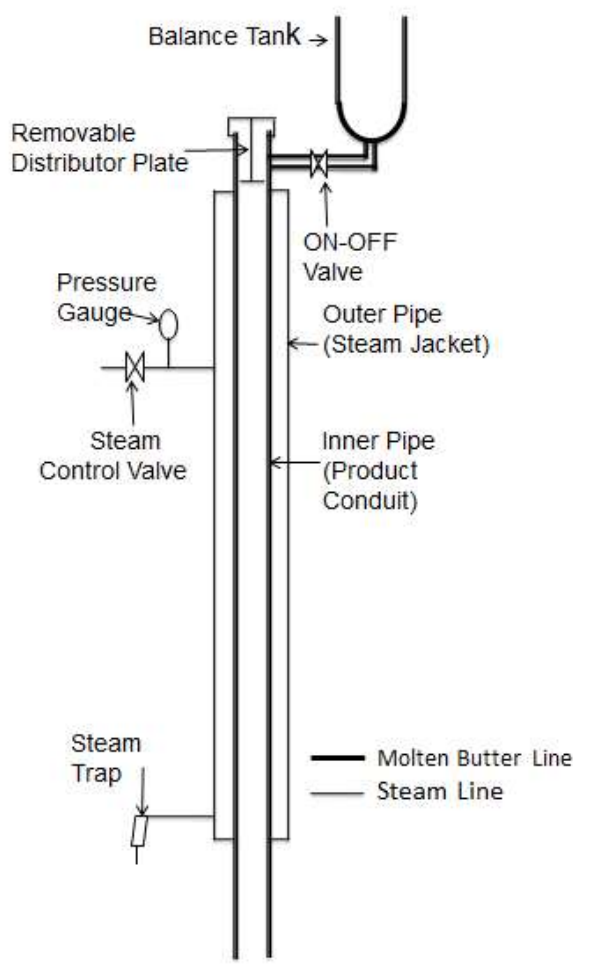

a) Schematic Diagram of STFFE prototype

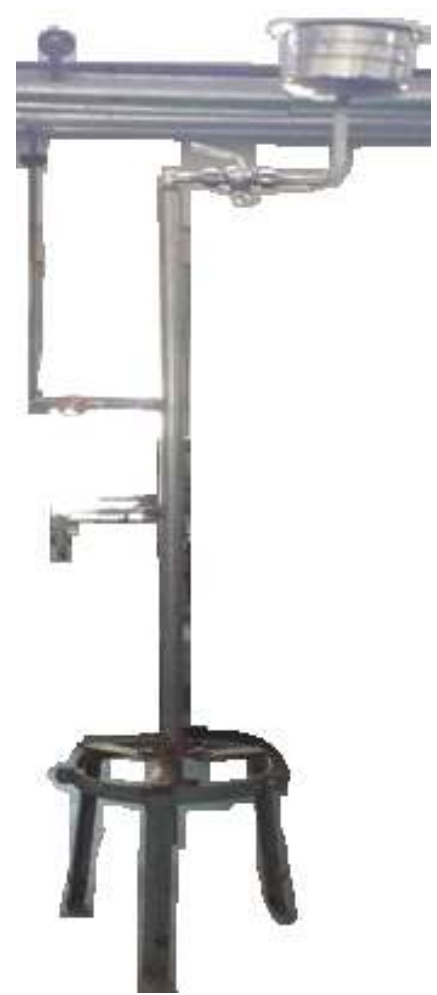

b) Fabricated STFFE prototype

Table 2 Technical specification of multi-tube falling film evaporator (MTFFE) prototype

\begin{tabular}{lc}
\hline Particulars & Value (mm) \\
\hline Diameter of shell (inner side) & 123 \\
Diameter of shell (outer side) & 130 \\
Diameter of tubes (inner side) & 22 \\
Diameter of tubes (outer side) & 25 \\
Diameter of distributor hood or system & 136 \\
Thickness of shell & 3.5 \\
Thickness of tubes & 1.5 \\
Thickness of separator cover & 6.75 \\
Thickness of tube sheet & 6.75 \\
Thickness of distributor plate & 3 \\
Height of pre-distributor plate & 30 \\
Diameter of pre-distributor plate & 40 \\
Height of distributor plate above the tube sheet & 40 \\
Diameter of distribution holes in distributor plate & 3 \\
Feed pipe diameter (inner side) & 9 \\
Feed pipe diameter (inner side) & 13 \\
Thickness of feed pipe & 2 \\
Size of sight glass & $80 \times 80$ \\
Size of steam inlet and outlet socket & 25 \\
Size of steam trap & 25 \\
\hline
\end{tabular}

$1.9 \mathrm{kgf} / \mathrm{cm}^{2}, 2.3 \mathrm{kgf} / \mathrm{cm}^{2}$, and $2.8 \mathrm{kgf} / \mathrm{cm}^{2}$ steam pressures, respectively (Fig. 5a). With increase in steam pressure, saturation temperature (evaporating temperature) increased. Chen and Jebson (1997) reported that the heat transfer coefficient increased 
Figure 2 Multi-tube Falling Film Evaporator (MTFFE) prototype (a) Schematic Diagram and (b) Fabricated MTFFE

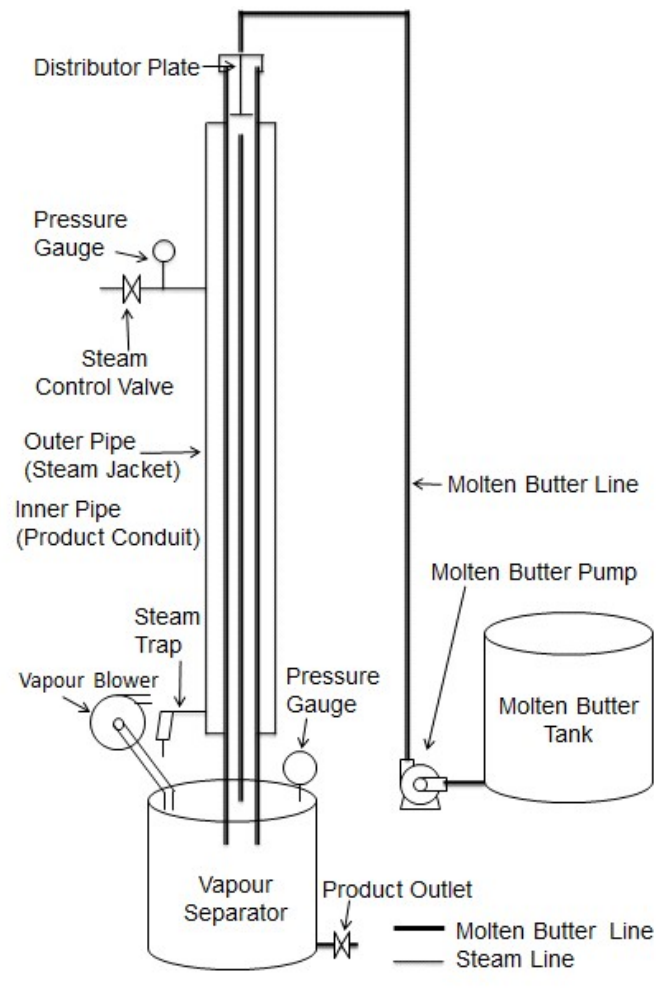

a) Schematic Diagram of STFFE prototype

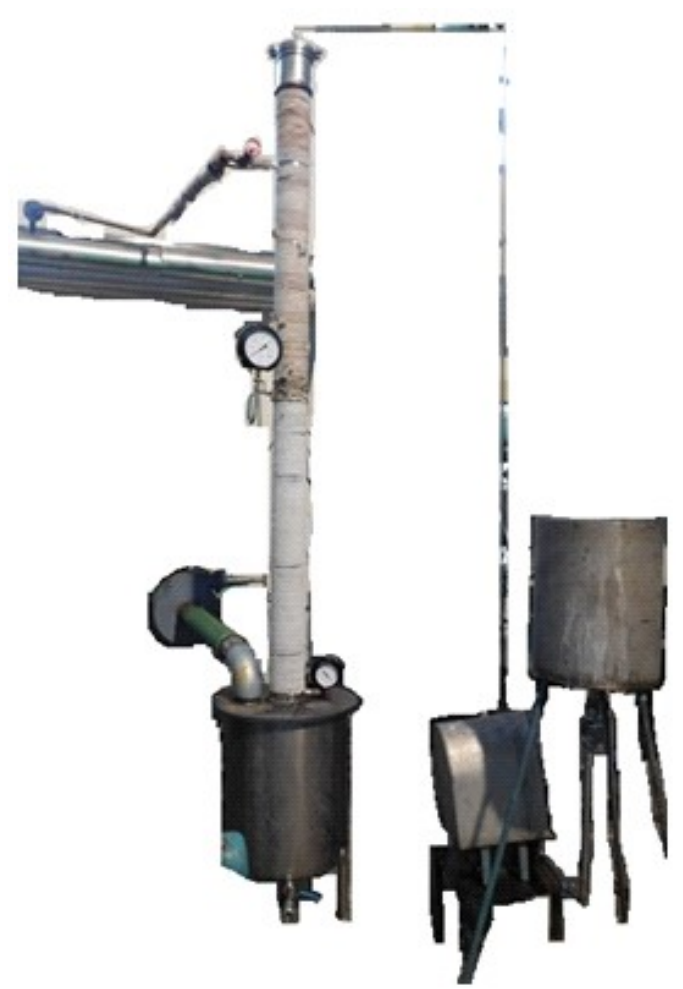

b) Fabricated MTFFE prototype

Table 3 Two- way ANOVA for steam economy, specific steam consumption, evaporation rate ( $\mathrm{kg} / \mathrm{min})$ and evaporation ratio for molten butter at various film thickness (FT) and steam pressure (SP) on STFFE

\begin{tabular}{llllll}
\hline Source & & DF & Mean Square & F Value & Pr $>$ F \\
\hline Steam economy & & & & & \\
& FT & 2 & 3.4713 & 9402.13 & $<.0001$ \\
& SP & 2 & 0.0299 & 81.23 & $<.0001$ \\
Specific steam consumption & FT $\times$ SP & 4 & 0.0309 & 83.8 & $<.0001$ \\
& & & & & $<.0001$ \\
Evaporation rate & FT & 2 & 1.9532 & 4001.9 & $<.0001$ \\
& SP & 2 & 0.0494 & 101.3 & $<.0001$ \\
& FT $\times$ SP & 4 & 0.0568 & 116.44 & $<.0001$ \\
Evaporation ratio & & & & & $<.0001$ \\
& FT & 2 & 0.0130 & 346.83 & $<.0001$ \\
& SP & 2 & 0.0028 & 76.73 & $<.0001$ \\
& FT $\times$ SP & 4 & 0.0007 & 20.71 & $<.0001$ \\
& & & & & $<.0001$ \\
\hline
\end{tabular}

as the evaporating temperature increased and as the heat transfer coefficient increases, the evaporation will increase. Therefore, steam economy was higher at higher steam pressures. With pump speed, it ranged from 0.67 to 1.03 and 0.63 to 1.06 for $285 \mathrm{rpm}$ and $320 \mathrm{rpm}$, respectively. This may occur due to the increasing the steam pressures, the saturation temperature increases and hence temperature gradient increases in MTFFE. It was observed that average capacity of butter processed (feed rate) were $1.45 \mathrm{~kg}$ / min and $3.01 \mathrm{~kg} / \mathrm{min}$ for STFFE and MTFFE, respectively. 

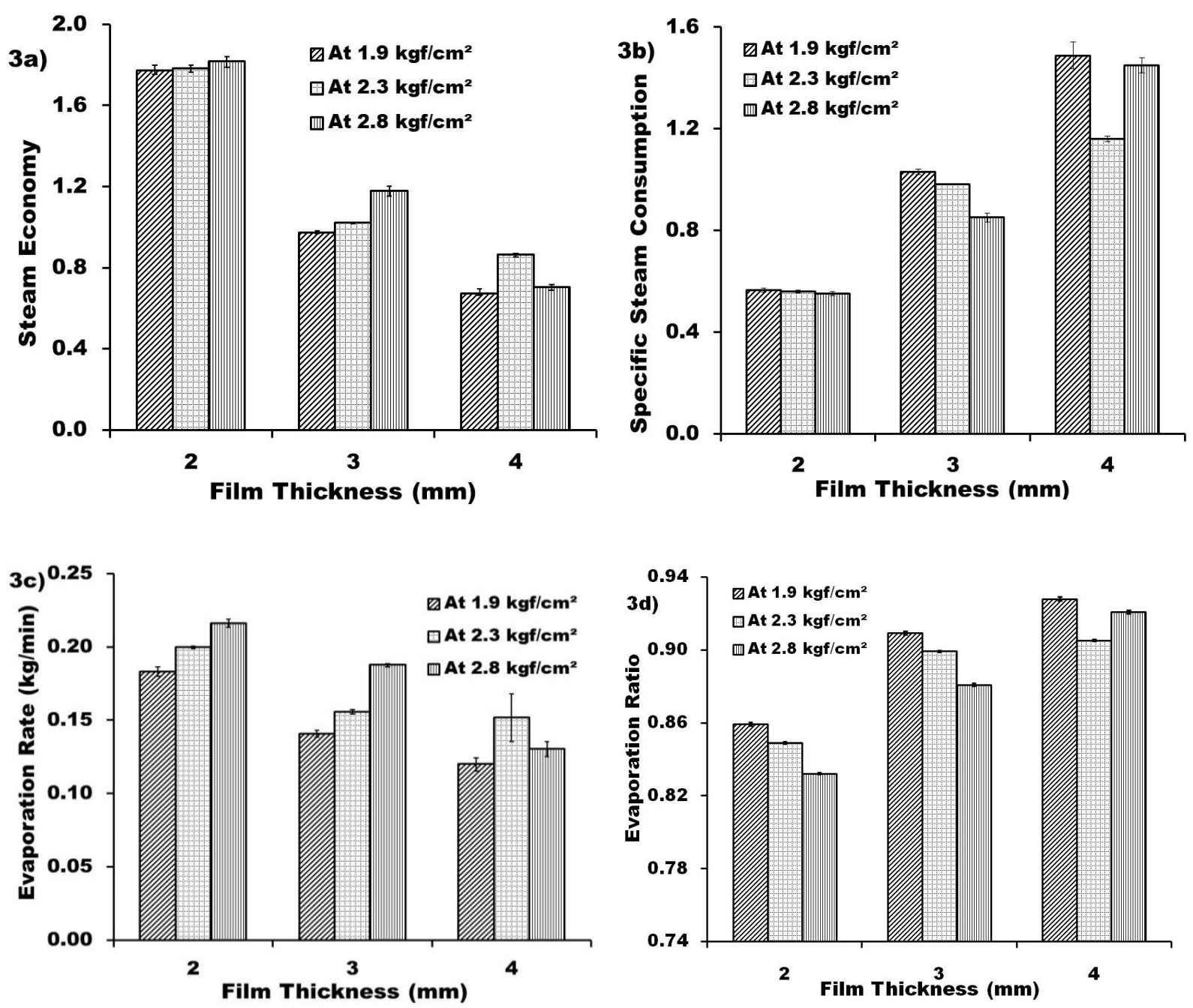

Figure 3 Effect of steam pressures and film thicknesses for single tube falling film evaporator for molten butter on (a) steam economy (b) specific steam consumption (c) evaporation rate, $\mathrm{kg} / \mathrm{min}$ and (d) evaporation ratio

\section{Specific steam consumption}

In case of STFFE, from Table 3, it is clear that specific steam consumption was significant with affecting factors and there interaction effect (at $\mathrm{p} \leq 0.05)$. The steam consumption was observed to be increased with increase in the film thicknesses (Fig. 3b). It was found that $2 \mathrm{~mm}$ of film thickness was much better in terms of operational cost. The average specific steam consumption ranged from 0.55 to $0.57,0.85$ to 1.03 , from 1.17 to 1.46 for $2 \mathrm{~mm}, 3 \mathrm{~mm}$, and $4 \mathrm{~mm}$ film thicknesses, respectively. The lower thickness might have increased the heat transfer and evaporation rate because of less mass of the film thickness. From experimental trials using water on MTFFE, Table 4 shows that all factors and their interaction were statistically significant $(\mathrm{p} \leq 0.05)$. The average specific steam consumption for $95^{\circ} \mathrm{C}$ initial temperature of water, ranged from 1.11 to 1.14 and 1.04 to 1.10 at $1.5 \mathrm{kgf} / \mathrm{cm}^{2}$ and $2 \mathrm{kgf} / \mathrm{cm}^{2}$ steam pressures, respectively. Its average specific steam consumption at $1.5 \mathrm{kgf} / \mathrm{cm}^{2}$ and $2 \mathrm{kgf} / \mathrm{cm}^{2}$ steam pressures for $40^{\circ} \mathrm{C}$ initial temperature of water, ranged from 1.06 to 1.59 and 0.99 to 1.12 , respectively (Fig.4b). Using molten butter in MTFFE, two-way ANOVA shows that specific steam consumption is highly significant with steam pressure whereas it is non-significant with pump speed and their interaction (Table 5). From Fig.5b, it was observed that specific steam consumption decreases with increase in steam pressure. It's average value ranged from the 1.50 to $1.59,1.09$ to 1.11 and 0.94 to 0.97 at 1.9 $\mathrm{kgf} / \mathrm{cm}^{2}, 2.3 \mathrm{kgf} / \mathrm{cm}^{2}$, and $2.8 \mathrm{kgf} / \mathrm{cm}^{2}$ steam pressures, respectively (Fig. 5b). With pump speed, it ranged from 0.97 to 1.50 and 0.94 to $1.59 \mathrm{~kg} / \mathrm{min}$ for $285 \mathrm{rpm}$ and $320 \mathrm{rpm}$, respectively. The decrease in the specific steam consumption with increase in steam pressure may occur because of increasing the steam pressures, the steam temperature increases and hence temperature difference in steam and molten butter temperature. 
Figure 4: Effect of steam pressures and film thicknesses for multi-tube falling film evaporator for water on (a) steam economy (b) specific steam consumption and (c) evaporation rate, $\mathrm{kg}$ / $\min$
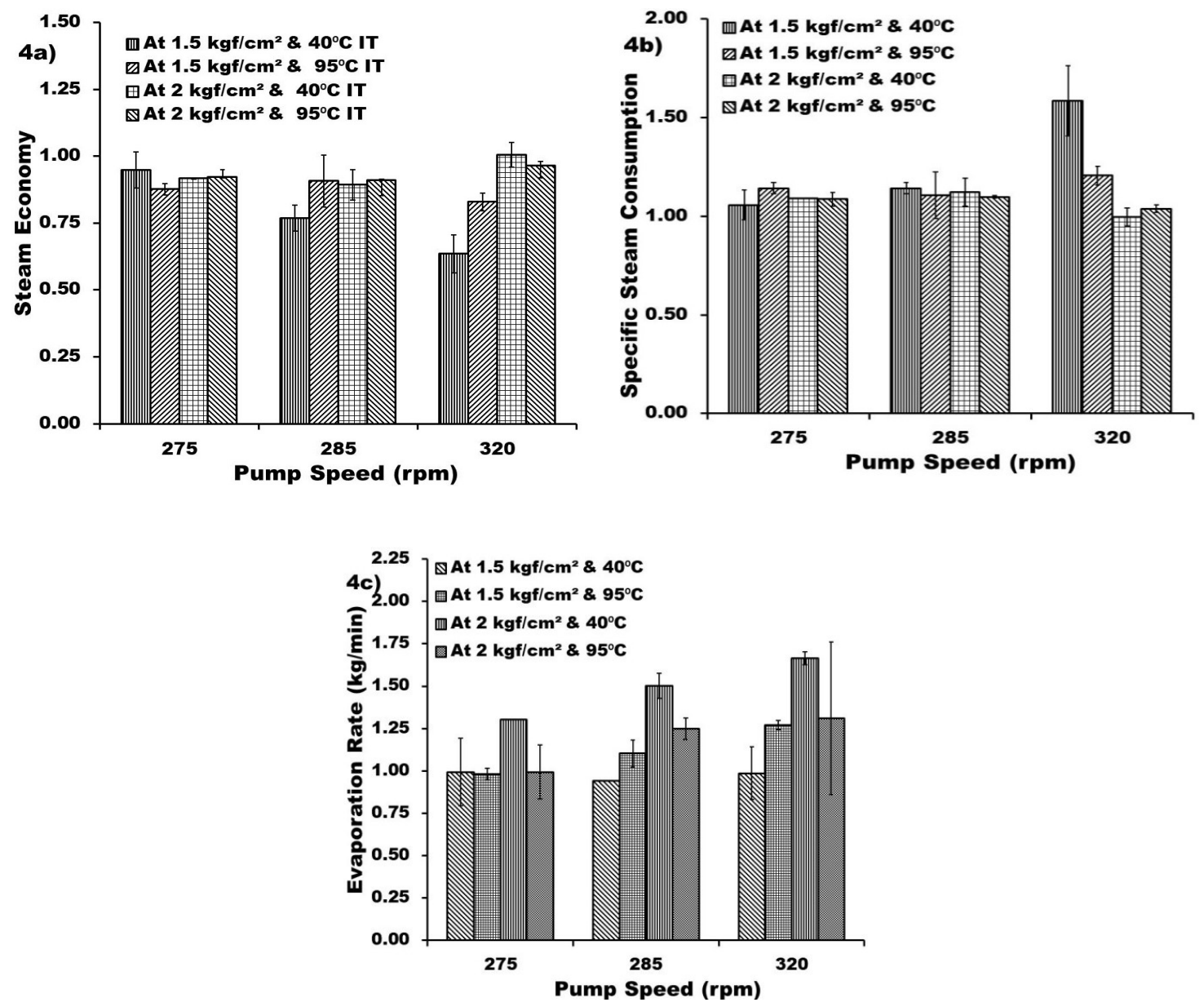

Table 4 Two-way ANOVA for steam economy, specific steam consumption and evaporation rate ( $\mathrm{kg} / \mathrm{min})$ for water at various steam pressure (SP), pump speed (PS) and initial temperature (IT) on MTFFE

\begin{tabular}{lllll}
\hline Source & DF & Mean Square & F Value & Pr $>$ F \\
\hline Steam economy & & & & \\
SP & 2 & 0.0374 & 14.49 & 0.0005 \\
PS & 2 & 0.0072 & 2.8 & 0.0976 \\
IT & 1 & 0.0099 & 3.85 & 0.0715 \\
SP $\times$ PS $\times$ IT & 2 & 0.0124 & 4.82 & 0.0272 \\
Specific steam consumption & & & \\
SP & 2 & 0.0821 & 13.52 & 0.0007 \\
PS & 2 & 0.0252 & 4.15 & 0.0403 \\
IT & 1 & 0.0383 & 6.31 & 0.0260 \\
SP $\times$ PS $\times$ IT & 2 & 0.0324 & 5.34 & 0.0203 \\
Evaporation rate & & & & $<.0001$ \\
SP & 2 & 0.7617 & 31.38 & 0.0275 \\
PS & 2 & 0.1165 & 4.8 & 0.2249 \\
IT & 1 & 0.0394 & 1.62 & 0.5552 \\
SP $\times$ PS $\times$ IT & 2 & 0.0149 & 0.62 & \\
\hline
\end{tabular}

\section{Evaporation rate}

For STFFE, evaporation rate was statistically highly significant (Table 3). Evaporation rate was calculated by amount of the moisture evaporated and time of operation (Eq.4). For the lower 

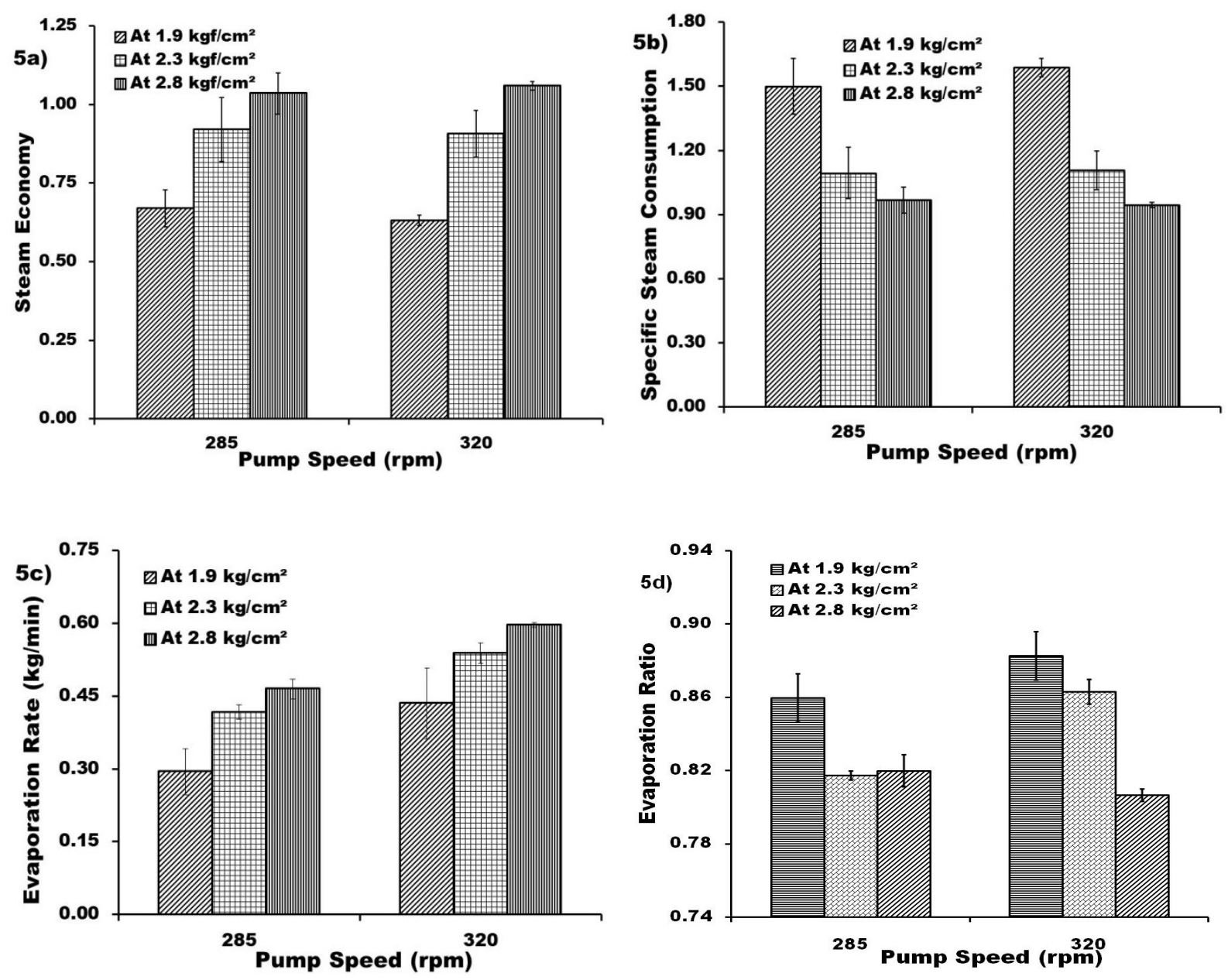

Figure 5: Effect of steam pressures and film thicknesses for multi-tube falling film evaporator for molten butter on (a) steam economy (b) specific steam consumption (c) evaporation rate, $\mathrm{kg} / \mathrm{min}$ and (d) evaporation ratio

film thickness, higher evaporation rate was observed as it took less time. This is because of the lower film thickness may provide the higher pool boiling in falling film heat transfer for the same time. The average evaporation rate ranged from 0.18 to $0.21,0.14$ to 0.18 and 0.13 to $0.15 \mathrm{~kg} / \mathrm{min}$ for $2 \mathrm{~mm}, 3 \mathrm{~mm}$, and $4 \mathrm{~mm}$ film thicknesses, respectively (Fig.3c). For water on MTFFE, twoway ANOVA indicates that steam pressure and pump speed were significant $(\mathrm{p} \leq 0.05)$ whereas initial temperature and the factors interaction were highly non-significant (Table 4 ). The average evaporation rate ranged from 0.98 to $1.30 \mathrm{~kg} / \mathrm{min}, 0.94$ to $1.50 \mathrm{~kg} /$ min and 0.98 to $1.66 \mathrm{~kg} / \mathrm{min}$ for $275 \mathrm{rpm}, 285 \mathrm{rpm}$, and $320 \mathrm{rpm}$, respectively for studied steam pressures $\left(1.5 \mathrm{kgf} / \mathrm{cm}^{2}\right.$ and $2 \mathrm{kgf} /$ $\mathrm{cm}^{2}$ ) (Fig. 4c). MTFFE on molten butter, evaporation rate was highly significant with steam pressure and pump speed and whereas their interaction was non-significant (Table 5). The average evaporation rate ranged from the 0.29 to $0.43,0.42$ to 0.54 and 0.46 to 0.60 at $1.9 \mathrm{kgf} / \mathrm{cm}^{2}, 2.3 \mathrm{kgf} / \mathrm{cm}^{2}$, and $2.8 \mathrm{kgf} / \mathrm{cm}^{2}$ steam pressures, respectively. With pump speed, average evaporation rate ranged from 0.29 to $0.46 \mathrm{~kg} / \mathrm{min}$ and 0.43 to $0.60 \mathrm{~kg} / \mathrm{min}$ for $285 \mathrm{rpm}$ and $320 \mathrm{rpm}$, respectively (Fig. 5c). It was found that evaporation rate decreased with decrease in the steam pressure and pump speed due to increase in viscosity. Dodeja and Deep (2012) also reported that evaporation rate decreases due to high concentration and viscosity.

\section{Evaporation ratio}

In case of STFFE, from Table 3, it was inferred that evaporation ratio was statistically highly significant $(\mathrm{p} \leq 0.05)$. The average evaporation ratio was found to be ranged from 0.83 to $0.86,0.84$ to 0.91 , and 0.90 to 0.92 for $2 \mathrm{~mm}, 3 \mathrm{~mm}$, and $4 \mathrm{~mm}$ film thicknesses respectively (Fig. 3d). It was observed that lower the film thickness, lower was the evaporation ratio. This means that higher concentration takes place with lower film thickness. For operation of MTFFE on molten butter, Table 5 shows that evaporation ratio 
Table 5 Two ways ANOVA for steam economy, specific steam consumption, evaporation rate $(\mathrm{kg} / \mathrm{min})$ and evaporation ratio for molten butter at various steam pressure (SP), pump speed (PS) and initial temperature (IT) on MTFFE

\begin{tabular}{|c|c|c|c|c|}
\hline Source & $\mathrm{DF}$ & Mean Square & F Value & $\operatorname{Pr}>\mathrm{F}$ \\
\hline \multicolumn{5}{|l|}{ Steam economy } \\
\hline SP & 2 & 0.1633 & 40.84 & 0.0003 \\
\hline PS & 1 & 0.0002 & 0.07 & 0.7995 \\
\hline $\mathrm{SP} \times \mathrm{PS}$ & 2 & 0.0009 & 0.25 & 0.7898 \\
\hline \multicolumn{5}{|c|}{ Specific steam consumption } \\
\hline SP & 2 & 0.3747 & 49.25 & 0.0002 \\
\hline PS & 1 & 0.0019 & 0.26 & 0.6269 \\
\hline $\mathrm{SP} \times \mathrm{PS}$ & 2 & 0.0031 & 0.42 & 0.6777 \\
\hline \multicolumn{5}{|l|}{ Evaporation rate } \\
\hline $\mathrm{SP}$ & 2 & 0.0287 & 19.91 & 0.0022 \\
\hline PS & 1 & 0.0516 & 35.73 & 0.001 \\
\hline $\mathrm{SP} \times \mathrm{PS}$ & 2 & 0.0001 & 0.07 & 0.9373 \\
\hline \multicolumn{5}{|l|}{ Evaporation ratio } \\
\hline $\mathrm{SP}$ & 2 & 0.0034 & 24.75 & 0.0013 \\
\hline PS & 1 & 0.0010 & 7.49 & 0.0338 \\
\hline $\mathrm{SP} \times \mathrm{PS}$ & 2 & 0.0009 & 6.52 & 0.0313 \\
\hline
\end{tabular}

was statistically significant with steam pressure and pump speed and their interaction $(\mathrm{p} \leq 0.05)$. Lower the evaporation ratio, better performance of the evaporation system. The average evaporation ratio ranged from the 0.86 to $0.88,0.82$ to 0.86 and 0.81 to 0.82 at $1.9 \mathrm{kgf} / \mathrm{cm}^{2}, 2.3 \mathrm{kgf} / \mathrm{cm}^{2}$, and $2.8 \mathrm{kgf} / \mathrm{cm}^{2}$ steam pressures, respectively. With pump speed, it ranged from 0.82 to 0.86 and 0.81 to 0.88 for $285 \mathrm{rpm}$ and $320 \mathrm{rpm}$, respectively (Fig. $5 \mathrm{~d}$ ). This may occur due to steep rise in the steam temperature which results in more concentration.

\section{Conclusions}

Single tube and multi tube falling film evaporator (STFFE and MTFFE) prototypes were developed and their evaporative performances were experimentally evaluated for molten butter. Evaporative performance parameters were statistically significant $(p \leq 0.05)$ for studied film thicknesses and steam pressures and their interactions on STFFE. It was found that higher film thickness resulted in lower steam economy, higher specific steam consumption, lower evaporation rate and higher evaporation ratio. For the studied steam pressures, average steam economy (1.75 to 1.80 ) and evaporation rate $(0.18$ to $0.21 \mathrm{~kg} / \mathrm{min})$ was highest whereas average evaporation ratio ( 0.83 to 0.86 ) was lowest for 2 $\mathrm{mm}$ film thickness. For MTFFE on molten butter, evaporative performance parameters were statistically significant $(\mathrm{p} \leq 0.05)$ for studied steam pressures. The evaporation rate and evaporation ratio were statistically significant and steam economy and specific steam consumption were statistically non-significant $(\mathrm{p} \leq 0.05)$ for studied pump speed. The highest steam economy and evaporation rate whereas lowest specific steam consumption and evaporation ratio were obtained at $2.8 \mathrm{kgf} / \mathrm{cm}^{2}$ steam pressure and $320 \mathrm{rpm}$ pump speed.

\section{References}

Ahmed T (2003) Dairy Plant Engineering and Management, KitabMahal Publication, ISBN 8122501184, pages 816

Anon (2019). https://www.idfa.org/docs/default-source/d-news/world-dairysituationsample.pdf, accessed 25 November 2018

Billet R (1989) Evaporation Technology: Principles, Applications. Economics, VCH, Weinheim

Bouman S, Brinkman DW, De JP, Waalewijn R (1988)Multistage evaporation in the dairy industry: energy saving, product losses and cleaning. Elsevier Science, Amsterdam

CBSE (2013) Dairy Products Technology. Fluid Milk Processing Student's Handbook for Class XI. Central Board of Secondary Education, New Delhi

Chen CS, Hernandez E (1997) Design and performance evaluation of evaporation. In Handbook of food engineering practice (pp. 216257). CRC Press

Chen, H, Jebson, RS (1997) Factors Affecting Heat Transfer In Falling Film Evaporators ,Trans Icheme, Part C, 75: 111-116

Cunningham P, Canty N, O'Mahony T, O'Connor B, O'Callaghan D (2006) System Identification of a Falling-Film Evaporator In The Dairy Industry. In proceedings of the UK Automatic Contro Conference, Sheffield

De S (1980) Outlines of Dairy Technology. Oxford University Press, ISBN 9780195611946, pages 539

Dodeja AK, Deep A (2012) Mechanized manufacture of danedar khoa using three stage SSHE. Indian J Dairy Sci 65(4): 274-284

FAO (2017) Milk and Milk Products: Price and Trade Update. Trade and Markets Division (EST), Food and Agriculture Organization of the United Nations. Rome. http://www.fao.org/3/a-i8326e.pdf. Accessed 15 March 2018

FSSAI (2012).Manual of methods of analysis of foods, milk and milk products. Food safety and standards authority of India, pp. 77

FSSAI (2015) Lab Methods of Analysis of Foods, Milk and Milk products Manual, Ministry of Health and Family Welfare, Government of India, New Delhi, 110011

Garg FC (2002) Anhydrous Milk Fat-Butter oil.In: Lecture Compendium of Advances In Fat Rich Dairy Products. Organised by Centre of Advanced Studies Dairy Technology Division, ICAR-NDRI, Karnal, India 
Kessler HG (1981) Food Engineering and Dairy Technology, Verlag A. Kessler, Germany

Lee CL, Liao HL, Lee WC, Hsu CK, Hsueh FC, Pan JQ, Chu CH, Wei CT,Chen MJ (2018) Standards and labeling of milk fat and spread products in different countries. J Food Drug Anal 26: 469-480

Minton PE (1986) Handbook of evaporation technology. Park Ridge, New Jersey, USA: Noyes Publications

Morison KR, Worth QAG, O'dea NP (2006) Minimum wetting and distribution rates in falling film evaporators. Trans IChemE, Part C, Food and Bioproducts Processing 84(C4): 302-310

Perry RH, Green DW (1997) Perry's Chemical Engineering Handbook

Písecký J (1997) Handbook of Milk Powder Manufacture. Niro, A/S, Denmark
Salvagnini WM, Taqueda ME (2004) A falling-film evaporator with film promoters. Industrial and Engineering Chemistry Research 43(21): 6832-6835

Snoeren THM, Damman AJ, Klok HJ (1982) The viscosity of skim-milk concentrates. Neth Milk Dairy J 36: 305-316

Tanguy G, Dolivet A, Garnier-Lambrouin F, Méjean S, Coffey D, Birks T, Jeantet R, Schuck P (2015) Concentration of dairy products using a thin film spinning cone evaporator. J Food Eng 166: 356-363

Warrior, AS, Sawhney, IK, Minz, PS (2018) Evaluation of effect of heating medium on the performance of a size reduction grid attached to a butter melter. Indian J Dairy Sci 71(5): 447-454 